\title{
Mapping geomorphosites: an analysis of geotourist maps
}

Kartowanie geoobiektów: analiza map geoturystycznych

\author{
Géraldine Bissig \\ Institute of Geography, University of Lausanne, 1015 Lausanne, Switzerland \\ e-mail: geraldine.bissig@unil.ch
}

\begin{abstract}
Within the current research on geomorphosites, the field of mapping is relatively little developed. Studies offering specific mapping methods for geomorphosites are still rare. However, we can observe an important production of maps used for tourism means: "geotourist maps". This study focuses on such maps. The statistical analysis of fifty or so geotourist maps has allowed us to group them into five categories. This article will discuss the statistical method used (hierarchical cluster analysis) as well as the results obtained. The maps are described according to their graphic components and study of their use illustrates their shortcomings in terms of the transfer of geoscience information. In conclusion, we offer some possibilities for the improvement of geomorphosite mapping for tourist use.
\end{abstract}

Keywords: geomorphosites, mapping, geotourism, interpretation

Treść: Kartowanie geoobiektów jest dziedzinq względnie zacofana $w$ stosunku do innych aspektów ich badań. Rzadko ukazuja się prace poświęcone specyficznym metodom kartowania tych obiektów, natomiast na rynku pojawia się coraz więcej map „geoturystycznych”. Niniejszy artykut poświęcony jest wtaśnie temu typowi map. Pokazano zastosowanie hierarchicznej analizy klastrowej do analizy statystycznej około pięćdziesięciu map geoturystycznych, co pozwoliło na wyróżnienie pięciu typów tych map. Zostaty one opisane z punktu widzenia sktadników graficznych i zastosowania. Wykazano ograniczenia w sposobie przekazywania informacji z zakresu nauk o Ziemi. We wnioskach zaproponowano usprawnienie kartowania geoobiektów dla celów turystycznych.

Slowa kluczowe: obiekty geoturstyczne, kartowanie, geoturystyka, interpretacja

\section{Introduction}

Over the last few years, geoscience researchers have been focusing their activities on geological or geomorphological objects of importance for the geosciences: geomorphosites. For some of these researchers (Strasser et al., 1995; Grandgirard, 1997), this importance refers essentially to the scientific characteristics of a site, i.e., geomorphosites are valuable as important witnesses of the history of the Earth, the evolution of the landscape or the climate. Others also invest geomorphosites with additional cultural, aesthetic, economical or ecological values (Panizza \& Piacente, 1993, 2003; Reynard, 2004, 2005).

From boosting the value of individual geomorphosites to the creation of geoparks (Frey, 2001), several methods for valorisation have been developed over the last few years: thematic walks, brochures and didactic panels, guided excursions, conferences, and geo-events. Leisure and recreation activities based on geological and geomorphological resources and aiming at interpretations of the latter can also be grouped under the notion of geotourism (Newsome \& Dowling, 2006).
Research accompanying the valorisation of these sites has developed methods of evaluation of scientific quality (Grandgirard, 1999; Coratza \& Giusti, 2005) and additional values (Reynard et al., 2007) of the geomorphosites. Utilisation values are taken into consideration in the studies of Bruschi \& Cendrero (2005), Serrano (2005) and Pereira et al. (2007). Pralong (2005) has developed a more specific method for evaluating the tourist potential of sites. At the same time, mapping methods (Carton et al., 2005) have been elaborated. In the domain of didactics, interpretation techniques have been proposed by several authors (Hose, 2006; Kruhl, 2006; Wölfl, 2006).

In this article, we will focus on the use of the map media in the geotourist field. The role of geomorphosite maps is discussed before presenting the state-of-the-art of research in this field. The analysis of a series of maps forms the heart of this article. By undertaking a Hierarchical Cluster Analysis (HCA), we were able to identify different types of maps. These types will be described according to their graphic characteristics, their content, as well as their field of application.

\section{The role of maps in the geotourism field}

Within the domain of geotourism, the map can intervene at two different levels. F or geotourism professionals - managers of a geopark, for example - the map can provide numerous services as a work tool. As a geodatabase, mapping and the detailed description of geomorphosites can be combined and completed with other spatial information (natural hazards, infrastructures and local services or the presence of other points of interest). Targeted requests can then allow a proximity analysis to be undertaken, which can, for instance, illustrate the distances of one or several sites to car parks, hostels, schools, etc. (Wang, 2006), generate thematic maps showing sections exposed to natural hazards (Pelfini et al., 2007) or which sites should be valorised in a specific thematic walkway. As such a database is easily updated it can also be used in the monitoring of sites.

As a communication tool, the map is also an application for the general public. The primary function of a map is often to serve as a $n$ orientation device. In this case, the different itineraries and points of interest are represented. Like a schema or diagram, a map can also be used as a method of visualising geoscientific information. This function is even more important as certain processes which contributed to the formation of a geomorphosite or a geomorphological landscape are no longer or not always clearly visible on the landscape. Thun, an illustration can facilitate understanding of the site and processes. 
Carton et al. (2005) proposed the terms of maps for specialists and maps for non-specialists to designate these two categories of users as outlined above.

\section{Geomorphosites mapping research - the state-of-the-art}

Although thematic maps concerning geomorphosites are elaborated in connection with inventories at different scales, no specific methodology for cartographical representation of geomorphosites is currently available (Bissig, 2007). The important variation observed in this domain, which is not only due to the different objectives of the maps, demonstrates this lack. The absence of a common methodology is explained by the relative infancy of geomorphosite research: these studies are still isolated and are not set within a wider framework (international level). Another explanation is the absence of international standards of geomorphological mapping (Gustavsson et al., 2006) which is often responsible for mapping of geomorphosites. Requirements varying from one project to another favour the variability of the representations.

Inspection of the geotourist maps for non-specialists leads to the same conclusion. As our analysis shows, the variability of maps is important and the only methodology that has been suggested is that developed at the University of Mondena e Reggio Emilia (Castaldini et al., 2005a, 2005b; Bertacchini et al., 2007). This methodology is based on the adaptation of maps for specialists to a general public. Such adaptation includes two main stages: (1) simplification of the classic map and (2) addition of basic tourist information. We have been unable to find information on the methodology applied for the production of numerous other geotourist maps.

Current studies on geotourist mapping focuse mainly on the optimisation of the visit conditions. We can highlight the suggestions of Carton et al. (2005) to integrate symbols and ideograms on maps indicating observation points (inner or outer observation points) or the best moment to visit a site depending on the light conditions. Other study groups have focused on the security of walkways. A method of evaluation of natural hazards and the vulnerability of visitors was recently proposed by Pelfini et al., 2007.

We cannot fail to notice that research questions turn more around "physical" preoccupations, like the protection or security of sites, rather than questions of communication and interpretation of geomorphosites. The exploration of sound mapping techniques, examination of the level of understanding and assimilation of information about the geomorphosites by the general public, are still in its beginnings (Bissig, in press).

\section{Analysis of the geotourist maps}

\section{Objectives of the study}

The study presented here focuses on the analysis of geotourist maps for non-specialists. Having collected numerous examples of maps over the years, we noticed the extreme variability of the maps in terms of both the graphic aspect (methods of representation) as well as the contents (elements represented). It was necessary to establish a typology of maps in order to facilitate an analysis of the function that maps ful- fil. Two questions guided our analysis: How are geomorphosites represented on the maps with a geotourist vocation? What is the importance of scientific and tourist information?

\section{Methods}

The analysis is based on a set of maps collected at international conferences on geoparks and geotourism. The sample was further enlarged following a call addressed to the European Geoparks Network (EGN) in autumn, 2006, inviting members to send in maps for this study. At the same time, the members of the Working Group on Geomorphosites of the International Association of Geomorphologists (IAG) were also invited to donate maps. Finally, 51 maps from eight European countries were analysed (table 1). Focusing our study only on the documents that could be brought on a visit, we have not considered any digital or interactive maps.

Table. 1. Origin of the maps studied.

\begin{tabular}{|l|c|}
\hline \multicolumn{1}{|c|}{ Country } & \multicolumn{1}{|c|}{$\begin{array}{c}\text { Number of } \\
\text { maps }\end{array}$} \\
\hline Italy/Wtochy & 19 \\
\hline Germany/Niemcy & 11 \\
\hline UK/Wielka Brytania & 7 \\
\hline Switzerland/Szwajcaria & 9 \\
\hline France/Francja & 2 \\
\hline Ireland/Irlandia & 1 \\
\hline Greece/Grecja & 1 \\
\hline Albania/Albania & 1 \\
\hline Total (Razem) & $\mathbf{5 1}$ \\
\hline
\end{tabular}

In order to elaborate typology of maps, the hierarchical cluster analysis (HCA) method was chosen. This method allows similar individuals to be grouped into homogenous classes basin on a set of defined criteria (Bavaud, 1999). The analysis of the criteria of each class then allows each group to be characterised from one to another. In order to be able to apply this statistical method, a table was generated where each map was broken down into different criteria ${ }^{1}$. These criteria were firstly translated into ordinal or categorial variables, which were then recoded to obtain numerical values. This process can be easily explained with the example of the scale criterion. In this case, there are three possible variables, each of which obtaining a score: small scale $=1$, medium scale $=2$, large scale $=3$.

Selection of the seven criteria for the statistical analysis (table 2) was guided by the pertinence of the criteria to mark a significant difference between the maps. The results of the HCA are displayed using a classification tree (or dendrogram), which shows the hierarchy of the groups. The number of groups retained is the result of a compromise allowing both a distinct and clear differentiation of the groups. In this particular case study, five groups were retained, which allows a pertinent typology to be established.

1 The entry table includes information and criteria relating to the following themes: identification of the map, form and format of the map, representation of the geo(morpho)logical contents, information regarding the visit as well as the offer and services of the region. 
Mapping geomorphosites

\begin{tabular}{|c|c|c|c|c|c|}
\hline \multicolumn{6}{|c|}{ Identification of the map (qualitative information) } \\
\hline & & Map name & Publisher & & \\
\hline & & Code & Year of publication & & \\
\hline & & Geopark & Place of publication & & \\
\hline & & Country & & & \\
\hline \multicolumn{6}{|c|}{ Map form and format Forma i format mapy } \\
\hline Scale * & Material & Format* & Map support* & Map background* & \\
\hline $\begin{array}{l}1=\text { small } \\
>1: 25,000\end{array}$ & $1=$ Paper & $1=$ small & $1=$ fold-up maps & $1=$ topographic & \\
\hline $\begin{array}{l}2=\text { medium } \\
1: 25,000\end{array}$ & $2=$ Numeric & $2=$ medium & $2=$ booklets or folders & $2=$ geologic & \\
\hline $\begin{array}{l}3=\text { large } \\
1:<25^{\prime} 000\end{array}$ & & $3=$ large & $\begin{array}{l}3=\text { maps found in } \\
\text { magazines or papers }\end{array}$ & $3=$ schematic & \\
\hline & & $4=$ screen & $4=$ website & $\begin{array}{l}4=3 \mathrm{D} \text { or } \\
\text { panoramic }\end{array}$ & \\
\hline & & & & $5=$ satellite image & \\
\hline & & & & $\begin{array}{l}6=\text { topographic and } \\
\text { geologic }\end{array}$ & \\
\hline \multicolumn{6}{|c|}{ Representation of the geomorphosites } \\
\hline & $\begin{array}{l}\text { Representation of } \\
\text { the geomorphosite* }\end{array}$ & $\begin{array}{l}\text { Delimitation of the } \\
\text { geomorphosite }\end{array}$ & Classification & $\begin{array}{l}\text { Geomorphosite } \\
\text { type }\end{array}$ & \\
\hline & $1=$ point symbols & $1=$ yes & $1=$ yes $)$ & $\begin{array}{l}1=\text { geomorpholo- } \\
\text { gic }\end{array}$ & \\
\hline & $\begin{array}{l}2=\text { pictorial } \\
\text { symbols }\end{array}$ & $2=$ no & $2=$ no & $2=$ geologic & \\
\hline & $\begin{array}{l}3=\text { classic } \\
\text { geosciences } \\
\text { mapping symbols }\end{array}$ & & & $3=$ other & \\
\hline & $\begin{array}{l}4=\text { limit of the } \\
\text { geomorphosites }\end{array}$ & & & & \\
\hline \multicolumn{6}{|c|}{ Visitor and tourist information } \\
\hline $\begin{array}{l}\text { Visitor } \\
\text { information* }\end{array}$ & $\begin{array}{l}\text { Kind of visitor } \\
\text { information }\end{array}$ & \begin{tabular}{|l} 
Tourist \\
infrastructure*
\end{tabular} & $\begin{array}{l}\text { Kind of tourist } \\
\text { infrastructure }\end{array}$ & $\begin{array}{l}\text { Features of } \\
\text { interest* }\end{array}$ & $\begin{array}{l}\text { Kind of features of } \\
\text { interest }\end{array}$ \\
\hline $0=$ none & $0=$ none & $0=$ none & $0=$ none & $0=$ none & $0=$ none \\
\hline $1=$ yes & $1=$ panoramic point & $1=$ yes & $1=$ car park & $1=$ yes & $\begin{array}{l}1=\text { historical or } \\
\text { cultural sites }\end{array}$ \\
\hline \multirow[t]{4}{*}{$2=$ several } & $2=$ trails & $2=$ several & $2=$ public transport & $2=$ several & $\begin{array}{l}2=\text { nature } \\
\text { observation (eg. bird } \\
\text { watching) }\end{array}$ \\
\hline & $\begin{array}{l}3=\text { information } \\
\text { centre }\end{array}$ & & $3=$ accommodation & & $3=$ others \\
\hline & $\begin{array}{l}4=\text { information } \\
\text { panels }\end{array}$ & & $4=$ picnic area & & \\
\hline & $5=$ others & & $5=$ others & & \\
\hline
\end{tabular}

Table 2. Entry table for the analysis of the geotourist maps with the coded criteria and variables.

* criteria used for the hierarchical cluster analysis.

\section{Results}

On the basis of the hierarchical cluster analysis, we have been able to establish a profile illustrating the distinctive characteristics of each group. The description of the common characteristics of each group has enabled us to propose a terminology for each group. This terminology reflects either the objective of the group or the target audience of the group of maps. Figure 2 presents each map type and schematises the principal characteristics of each group.

\section{Type 1: Index map}

Maps of the Type 1 are characterised by schematic representation (e.g., relief) and are of small scale. Geomorphosites are marked with punctual symbols indicating their location. This type of representation together with the lack of additional information does not allow the user to appreciate immediately the contents of the site: the scientific information, like the tourist information, is unsubstantial. This type of maps is often found in geopark information brochures and is called an index map. 


\section{Type 2: Tourist maps}

In comparison with Type 1, maps of Type 2 provide more tourist information such as picnic areas, car parks, accommodation, etc. For this reason these maps are called tourist maps. Due to the small scale of these often topographical or schematic maps, geomorphosites are always represented by punctual symbols. The scientific information is unsubstantial and the tourist information more or less satisfactory.

\section{Type 3 and 4: Geoscientific maps for amateurs of Earth sciences}

The term of Geoscientic map for amateurs of Earth sciences was chosen to designate the maps of small to large scales, which include an important geological and/or geomorphological component.

The distinction between types 3 and 4 is necessary due to the representation of the geomorphosites themselves, represented either as punctual symbols in the first case (Type 3) or by classic mapping symbols in the second case (Type 4). Consequently, the scientific content of the maps is high for both types. The tourist content varies between average (Type 3) and high (Type 4).

\section{Type 5: Interpretive maps}

The name "interpretive map" rests on the "interpretative" character of these maps. On one hand, sets of symbols or figurative symbols are projected on a large-scale, schematic background. This allows landscape forms to be shown. On the other hand, this type of maps offers a good mix of explanatory elements concerning the Earth sciences and the tourist information. (Fig. 1.)

\section{Discussion}

We were able to note earlier that the degree of complexity of the maps (in terms of scientific information) and the importance of the tourist information are extremely variable between the different types of maps. This changes from the index map, highlighting the location of different sites as the principal information (Type 1), to the geoscience map for amateurs of Earth sciences (types 3 and 4), which provide detailed geological, geomorphological and tourist information. As the diverse geotourist offers are set within a leisure context, the efficiency of the maps should also be considered. According to Lehnes \& Glawion (2006), visitors take up only these offers for which they have an impression that the benefits they will gain will be more important than the efforts invested. By applying this principle to the reading of the map, this means that the visitor would like to learn pertinent information without having to deliberate on a map for too long to gain an understanding.

Seen from this point of view, the index maps (Type 1) and the tourist maps (Type 2) are quite poor sources of information. Of course, these maps provide information on the points of interest in the region and, thus, can help in planning of a trip, particularly in selection of sites to be visited for which basic tourist information is available. On the other hand, such maps do not provide any immediate scientific information. This information must be gathered from the texts and photos accompanying the map.
The objective of the geoscience maps for amateurs of Earth sciences (types 3 and 4) clearly aims towards the communication of scientific content. These map provides detailed geological/geomorphological information. Despite a supposed simplification of the original map, the legends are complex (complete stratigraphy and lithology, numerous structural and tectonic elements), hence, a relevant geoscience knowledge is, in our opinion, necessary in order to use effectively this type of maps. We believe that the average user may become discouraged and may prefer to switch directly to the text and illustrations displayed at the margins or on the back of the map. Such maps would then serve more as a source of tourist information on the region. The balance between effort and benefits is not optimal.

In the case of interpretive maps (Type 5), we observed a definite effort of popularization. The territory represented is of a modest size, which allows the landforms to be clearly displayed. The figurative symbols used to designate the particular forms show on what the user needs to focus the attention. In this case the primary information has not only been simplified but also translated into a language easily understandable for non-specialists. The information that may be gained from the map itself (without turning into the accompanying text or illustration) is considerable. The tourist elements are also highlighted with the double aim of providing information on complementary activities and facilitating orientation to a maximum. This results in an easily readable maps.

It is interesting to combine these observations with the repartition of the maps within the five categories (fig 2). The basic maps (types 1 and 2) make up almost half (46\%) of studied population. Another important portion (38\%) is composed of maps targeted at an audience which is already familiar with the Earth sciences (types 3 and 4). The portion made up by interpretive maps, considered as the most efficient, is quite small $(16 \%)$.

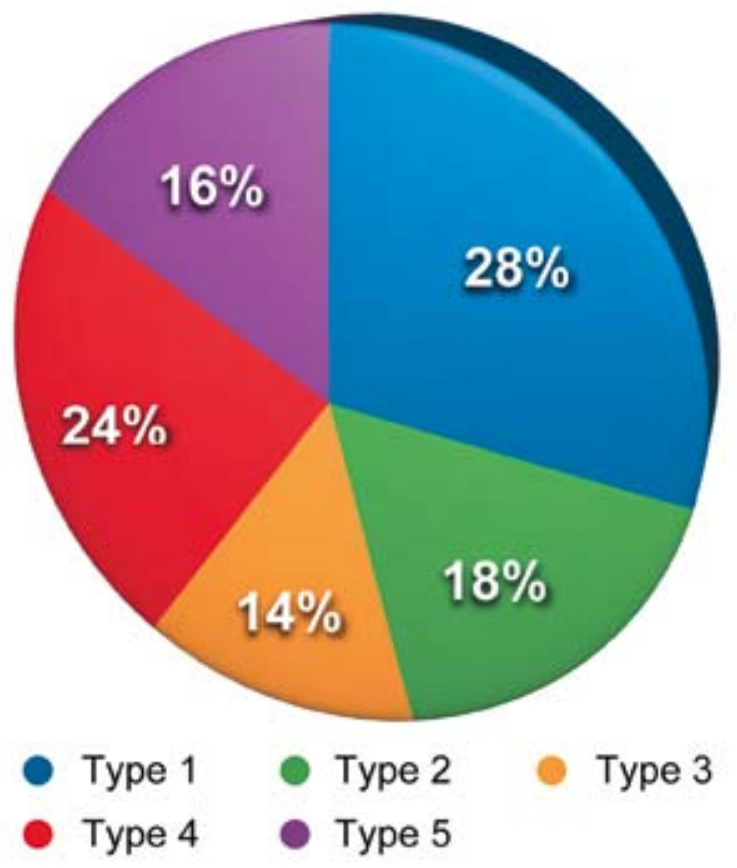

Fig. 2. Distribution of the maps according to the five categories • Udział procentowy pięciu typów map w badanej populacji 


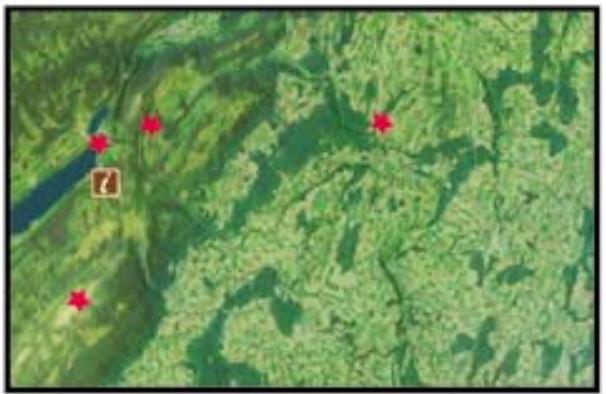

Type 1: Overview maps

Small scale

Booklets or folders

Schematic or satellite background

Punctual symbols

Few additional information
Typ 1: Mapy przeglądowe

Mała skala

Broszury, foldery

Podkład: mapa uproszczona lub satelitarna

Symbole punktowe

Uboga informacja dodatkowa
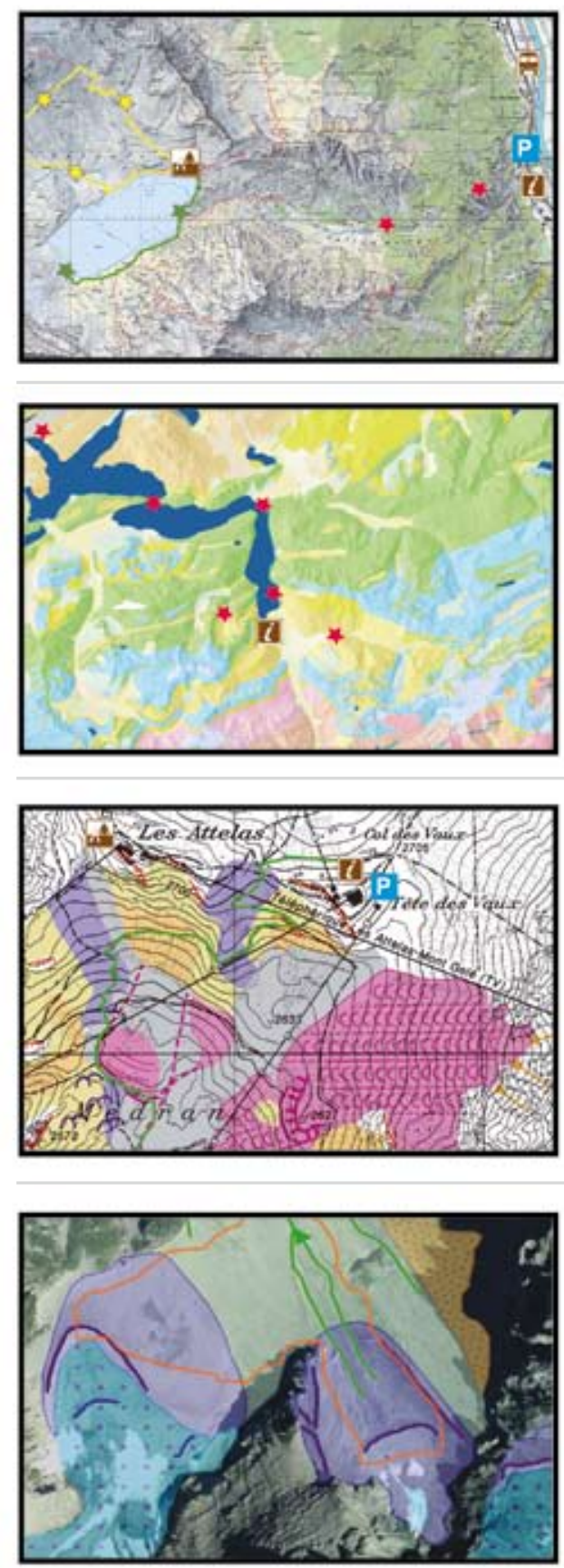

\section{Type 2: Geotourist maps}

Small scale

Booklets or folders

Topographic or geologic background

Punctual symbols

All kinds of additional information

\section{Typ 2: Mapy geoturystyczne}

Mała skala

Broszury, foldery

Podkład: mapa topograficzna lub geologiczna

Symbole punktowe

Wszechstronna informacja dodatkowa
Type 3: Geoscientific maps for amateurs of Earth sciences

Small scale

Fold-up maps

Topographic or geologic background

Punctual symbols

Few additional information

\section{Typ 3: Mapy przeznaczone dla} amatorów nauk o Ziemi

Mała skala

Mapa składana

Podkład: mapa topograficzna/ geologiczna

Symbole punktowe

Uboga informacja dodatkowa
Type 4: Geoscientific maps for amateurs of Earth sciences

Large scale

Fold-up maps

Topographic or geologic background

Classical geosciences mapping symbols

All kinds of additional information
Typ 4: Mapy przeznaczone dla amatorów nauk o Ziemi

Duża skala

Mapa składana

Podkład: mapa topograficzna i/lub geologiczna

Klasyczne symbole kartograficzne

Wszechstronna informacja dodatkowa

\section{Type 5: Geodidactic maps}

Large scale

Booklets or folders

Schematic background

Set of symbols or figurative symbols

All kinds of additional information

\section{Typ 5 Mapy geoedukacyjne}

Duża skala

Broszury, foldery

Podkład: mapa uproszczona

Specjalne zestawy symboli lub symbole obrazkowe

Wszechstronna informacja dodatkowa

* Geosites $=\begin{array}{ll}\text { Trails } \\ \text { Szlaki, ścieżki }\end{array} \quad \begin{aligned} & \text { Tourist and visitor information } \\ & \text { Informacja turystyczna }\end{aligned}$

Credits for map backgrounds: 1-3. swisstopo; 4. Lambiel \& Reynard, 2003; 5. Lambiel et al., 2008 • Źródła: 1-3. swisstopo; 4. Lambiel \& Renard, 2003; 5. Lambiel et al., 2008

Fig. 1 Schematic representation of the principal characteristics of the different types of maps $\bullet$ Schematyczne przedstawienie głównych cech różnych typów map 


\section{Conclusions}

On the contrary to what is practised in the domain of popularization (scientific mediation), where a lot has already been done on textual communication, the principles of vulgarisation still seem to be underdeveloped in regards to graphic information. The production of geotourist maps is undertaken according to unclear principles and appears to be guided more by aesthetic concerns than by didactic concerns. The analysis has shown that the communication potential of maps is currently largely underdeveloped. In order to improve the efficiency of maps, studies to illustrate the needs of visi- tors, that is, which determine their expectations and also the way they assimilate the information offered to them, are necessary (Pralong, 2006; Reynard \& Berrebi, under publication). The results of these studies will help improve the effectiveness of the maps and through this, improve the quality of the tourist offer.

\section{Acknowledgements}

We would like to thank all those who provided us with geotourist maps. Following our announcement through the working group, numerous people sent us articles about methodologies for geotourist maps and which we would not otherwise have had access to. We thank them all sincerely.

\section{Streszczenie}

Kartowanie geoobiektów: analiza map geoturystycznych

\author{
Géraldine Bissig
}

\section{Wstęp}

W ostatnich kilku latach naukowcy skupili uwagę na geoobiektach, tj. obiektach geologicznych i geomorfologicznych o istotnym znaczeniu dla nauk o Ziemi. Według części autorów (Strasser et al., 1995; Grandgirard, 1997) znaczenie tych obiektów polega przede wszystkim na ich wartości naukowej, tzn. są one ważnymi świadkami historii Ziemi, ewolucji krajobrazu czy zmian klimatycznych. Inni łączą geoobiekty z dodatkowymi wartościami: kulturowymi, estetycznymi, ekonomicznymi lub ekologicznymi (Panizza \& Piacente, 1993, 2003; Reynard, 2004, 2005). Wprowadzono też w ostatnich latach wiele sposobów oceny wartości i promowania geoobiektów (Frey, 2001). Wreszcie, polu zainteresowania geoturystyki mieści się także rekreacja wykorzystująca obiekty geologiczne i geomorfologiczne, z możliwością objaśniania ich genezy (Newsome \& Dowling, 2006).

W czasie jaki upłynął od opisu pierwszego geoobiektu do utworzenia geoparków rozwinięto metody oceny wartości naukowej geoobiektów (Grandgirard, 1999; Coratza \& Giusti, 2005) i innych wartości, jakie reprezentują (Reynard et al., 2007), w tym także użytkowych (Bruschi \& Cendrero, 2005; Serrano, 2005 and Pereira et al., 2007). Ponadto Pralong (2005) przedstawił własną metodę oceny potencjału turystycznego geoobiektów, a Carton et al. (2005) zaproponowali metody ich kartowania. W dziedzinie edukacji stworzono nowe techniki interpretacji geoobiektów (Hose, 2006; Kruhl, 2006; Wölfl, 2006).

Poniżej autorka przedstawia analizę i ocenę zestawu map geoobiektów z zastosowaniem metody hierarchicznej analizy klastrowej (Hierarchical Cluster Analysis, HCA), która pozwoliła na wydzielenie różnych typów map. Podano też charakterystykę ich strony graficznej, zawartości i zastosowania.

\section{Rola map w geoturystyce}

W geoturystyce mapy znajduja dwojakie zastosowanie. Dla profesjonalistów (np. pracowników geoparków) są one po prostu narzędziami pracy. Mapa wraz ze szczegółowymi opisami poszczególnych geoobiektów jest swoistą bazą danych, która może być uzupełniana innymi informacjami (np. o zagrożeniach naturalnych, infrastrukturze, usługach, obecności ciekawych obiektów o innym charakterze). Przy jej pomocy można przeprowadzać analizę danych, np. dla określenia odległości geoobiektów od parkingów, hosteli, szkół, itp. (Wang, 2006), można też tworzyć mapy tematyczne, np. pokazujące obszary w których mogą wystąpić naturalne zagrożenia środowiska (Pelfini et al., 2007) lub wskazać, które obiekty mogą być włączone do ścieżek tematycznych. Ponadto taka baza danych może być łatwo uaktualniana i służyć do monitoringu geoobiektów.

Mapy są także narzędziem komunikowania się, przydatnym zwykłemu turyście. W takim sensie służą one głównie jako przewodniki, a ich podstawową funkcją jest wskazywanie przebiegu szlaków turystycznych i położenia interesujących punktów. Podobnie jak schematy czy diagramy, mapy mogą być też użyte do wizualizacji danych o geoobiektach. Funkcja ta jest o tyle ważna, że procesy prowadzące do powstania geoobiektów czy kształtujące powierzchnię Ziemi są już niewidoczne lub słabo widoczne w krajobrazie. Dlatego Carton et al. (2005) zaproponowali tworzenie dwóch kategorii map - dla specjalistów i dla zwykłych turystów (niespecjalistów).

\section{Aktualny stan wiedzy o kartowaniu geoobiektów}

Mapy tematyczne geoobiektów przeznaczone dla specjalistów są wykonywane w różnych skalach. Mimo to nie istnieje, jak dotąd, jednolita metodyka ich kartograficznego odwzorowania (Bissig, 2007). Dowodzi tego wielka różnorodność map, której nie można wytłumaczyć jedynie znacznym zróżnicowaniem kartowanych obiektów. Brak takiej jednolitej metodyki spowodowany jest też tym, że badania geoobiektów są stosunkowo młodą dziedziną nauk o Ziemi i nie są koordynowane na szczeblu międzynarodowym. Innym powodem 
jest brak międzynarodowych standardów kartowania geomorfologicznego (Gustavsson et al., 2006), którego metodyka jest często wykorzystywana w kartowaniu geoobiektów.

Analiza map przeznaczonych dla zwykłych turystów prowadzi do takich samych wniosków. Różnorodność map turystycznych jest równie wielka jak map ,,profesjonalnych”, a jedyna propozycja metodyczna ich wykonywania pochodzi z Uniwersytetu Mondena e Reggio Emilia (Castaldini et al., 2005a, 2005b; Bertacchini et al., 2007) i jest oparta na przystosowaniu map wykonanych dla specjalistów do celów turystycznych. Taka adaptacja obejmuje dwa etapy: (1) uproszczenie map specjalistycznych i (2) dodanie podstawowej informacji turystycznej. Autorka nie znalazła żadnej informacji metodycznej dotyczącej innych map geoturystycznych, które były przedmiotem analizy.

Obecnie prowadzone kartowania geoturystyczne skupiają się głównie na optymalizacji warunków zwiedzania obiektów. Można tu zacytować pracę Carton et al. (2005), którzy sugerują integrację symboli i ideogramów stosowanych na mapach lub umieszczenie na nich informacji dodatkowej, np. dotyczącej najlepszej pory zwiedzania w zależności od warunków oświetlenia. Inne badania dotyczą bezpieczeństwa poruszania się po szlakach turystycznych. Metody oceny naturalnych zagrożeń na szlakach zaproponowali ostatnio Pelfini et al., (2007).

Zauważyć trzeba, że podejmowane dotychczas problemy badawcze dotyczą bardziej działań „fizycznych”, jak np. ochrona i bezpieczeństwo turystów w zwiedzanych miejscach, niż zagadnień objaśniania geoobiektów i przekazywania informacji turystom. Prace nad zastosowaniem różnych metod kartowania czy sprawdzanie poziomu przyswajania informacji o geoobiektach przez turystów są nadal w stadium początkowym (Bissig, w przygotowaniu).

\section{Analiza map geoturystycznych}

Analizę oparto na egzemplarzach map geoturystycznych, przeznaczonych dla nie-specjalistów. Autorka zebrała liczne egzemplarze map wydanych w ostatnich latach i stwierdziła ich ogromną różnorodność, zarówno pod względem graficznym, jak i pod względem treści. Zanim przeprowadzono analizę funkcji spełnianych przez mapy należało przeprowadzić ich klasyfikację na podstawie sposobu prezentowania geoobiektów na mapach turystycznych i prezentowanej informacji naukowej i turystycznej.

Do analizy wybrano zestaw map zebranych podczas międzynarodowych konferencji dotyczących geoparków i geoturystyki. Uzupełniono go egzemplarzami uzyskanymi od członków Europejskiej Sieci Geoparków (EGN), a także od członków grupy roboczej „,Working group on geomorphosites" działającej przy Międzynarodowej Asocjacji Geomorfologów (IAG). Pozwoliło to zebrać populację liczącą 51 map z 8 krajów europejskich (Tab. 1). Nie uwzględniono map interaktywnych i cyfrowych.

Do klasyfikacji map zastosowano metodę hierarchicznej analizy klastrowej (Hierarchical Cluster Analysis, HCA), która pozwala pogrupować podobne elementy w homogeniczne klasy przy zastosowaniu zespołu zdefiniowanych kryteriów (Bavaud, 1999). Analiza zastosowanych kryteriów

\begin{tabular}{|l|c|}
\hline \multicolumn{1}{|c|}{ Kraj } & Liczba map \\
\hline Włochy & 19 \\
\hline Niemcy & 11 \\
\hline Wielka Brytania & 7 \\
\hline Szwajcaria & 9 \\
\hline Francja & 2 \\
\hline Irlandia & 1 \\
\hline Grecja & 1 \\
\hline Albania & 1 \\
\hline Razem & $\mathbf{5 1}$ \\
\hline
\end{tabular}

Tab. 1. Pochodzenie badanej populacji map

prowadzi do sporządzenia charakterystyki każdej grupy i określenia różnic między grupami. W tym celu sporządzono tabelę, w której każdej analizowanej mapie przypisano odpowiednie kryteria klasyfikacyjne: nazwę, formę, format, sposób przedstawienia treści geologicznych i/lub geomorfologicznych, informacje turystyczne oraz ofertę usługową regionu. Kryteriom tym przyporządkowano cechy opisowe, którym następnie nadano wartości liczbowe. Jako przykład podać można skalę mapy, której przyporządkowano trzy wartości: skala mała $=1$, skala średnia $=2$ i skala duża $=3$.

Ostatecznie do analizy wybrano siedem kryteriów (Tab. 2), pozwalających wydzielić istotne różnice pomiędzy analizowanymi mapami. Wyniki analizy HCA przedstawiono w formie dendrogramu, ukazującego hierarchię poszczególnych grup.

\section{Wyniki badań}

Przy pomocy analizy HCA określono zespoły cech (profile) wyróżniające poszczególne grupy map i zaproponowano odpowiednią terminologię. Fig. 1 przedstawia przykłady reprezentatywne dla każdej grupy.

\section{Typ 1: Mapy przeglądowe}

Są to mapy o małej skali, charakteryzujące się schematycznym przedstawieniem szczegółów (np. morfologii terenu). Położenie geoobiektów zaznaczone jest przy pomocy symboli punktowych, brak jest natomiast dodatkowej informacji, umożliwiającej turyście ocenę atrakcyjności poszczególnych miejsc. Informacja naukowa i turystyczna jest niewystarczająca. Ten typ map spotykany jest często w materiałach informacyjnych wydawanych przez geoparki.

\section{Typ 2: Mapy geoturystyczne}

$\mathrm{W}$ porównaniu z mapami przeglądowymi, mapy geoturystyczne dostarczają więcej informacji przydatnej dla zwiedzających, np. położenie obszarów rekreacyjnych, parkingów, miejsc zakwaterowania. Są to często mapy topograficzne lub plany rysowane w małej skali, a geoobiekty zaznaczone sa symbolami punktowymi. Zawarta w nich informacja naukowa jest niewystarczająca, natomiast informacja turystyczna jest mniej lub bardziej zadowalająca.

\section{Typy 3 i 4: Mapy przeznaczone dla amatorów nauk o Ziemi}

Są to mapy wykonane zarówno w małych, jak i w dużych skalach, zawierające istotne informacje geologiczne $\mathrm{i} / \mathrm{lub}$ 
Mapping geomorphosites

\begin{tabular}{|c|c|c|c|c|c|}
\hline \multicolumn{6}{|c|}{ Identyfikacja mapy (dane jakościowe) } \\
\hline & & Nazwa & Wydawca & & \\
\hline & & Numer & Rok wydania & & \\
\hline & & Geopark & Miejsce wydania & & \\
\hline & & Kraj & & & \\
\hline \multicolumn{6}{|c|}{ Forma i format mapy } \\
\hline Skala* & Forma & Format* & \begin{tabular}{|l|} 
Sposób \\
rozpowszechniania*
\end{tabular} & Tło mapy* & \\
\hline $\begin{array}{l}1=\text { mała } \\
>1: 25,000\end{array}$ & $1=$ Drukowana & $1=$ mały & $1=$ mapa składana & $1=$ topograficzne & \\
\hline $\begin{array}{l}2=\text { średnia } \\
1: 25,000\end{array}$ & $2=$ Cyfrowa & $2=$ średni & $\begin{array}{l}2=\text { broszura lub } \\
\text { folder }\end{array}$ & $2=$ geologiczne & \\
\hline $\begin{array}{l}3=\text { duża } \\
1:<25^{\prime} 000\end{array}$ & & $3=$ duży & \begin{tabular}{|l}
3 = mapy \\
zamieszczone \\
w czasopismach \\
$i$ artykułach \\
\end{tabular} & $3=$ schematyczne & \\
\hline & & $4=$ rozmiar ekranu & $4=$ strona internetowa & $\begin{array}{l}4=\text { model } \\
\text { trójwymiarowy lub } \\
\text { panorama }\end{array}$ & \\
\hline & & & & $\begin{array}{l}5=\text { zdjęcie } \\
\text { satelitarne }\end{array}$ & \\
\hline & & & & $\begin{array}{l}6=\text { topograficzne } \\
\text { i geologiczne }\end{array}$ & \\
\hline \multicolumn{6}{|c|}{ Sposób przedstawienia geoobiektów } \\
\hline & $\begin{array}{l}\text { Sposób } \\
\text { przedstawienia } \\
\text { geoobiektów* }\end{array}$ & $\begin{array}{l}\text { Zaznaczenie granic } \\
\text { geoobiektów }\end{array}$ & Klasyfikacja & Typ geoobiektu & \\
\hline & $\begin{array}{l}1=\text { symbole } \\
\text { punktowe }\end{array}$ & $1=$ tak & $1=$ tak & $\begin{array}{l}1= \\
\text { geomorfologiczny }\end{array}$ & \\
\hline & $\begin{array}{l}2 \text { = symbole } \\
\text { obrazkowe) }\end{array}$ & $2=$ nie & $2=$ nie & $2=$ geologiczny & \\
\hline & $\begin{array}{l}3=\text { symbole } \\
\text { stosowane na } \\
\text { mapach } \\
\text { geologicznych lub } \\
\text { geograficznych } \\
\end{array}$ & & & $3=$ inny & \\
\hline & $\begin{array}{l}4=\text { granice } \\
\text { geoobiektów }\end{array}$ & & & & \\
\hline \multicolumn{6}{|c|}{ Informacja turystyczna } \\
\hline $\begin{array}{l}\text { Informacja } \\
\text { turystyczna* }\end{array}$ & $\begin{array}{l}\text { Sposób } \\
\text { przekazywania } \\
\text { informacji }\end{array}$ & $\begin{array}{l}\text { Infrastruktura } \\
\text { turystyczna* }\end{array}$ & $\begin{array}{l}\text { Rodzaje obiektów } \\
\text { infrastruktury } \\
\text { turystycznej }\end{array}$ & $\begin{array}{l}\text { Atrakcje } \\
\text { turystyczne* }\end{array}$ & Rodzaje atrakcji \\
\hline $0=$ brak & $0=$ brak & $0=$ brak & $0=$ brak & $0=$ brak & $0=$ brak \\
\hline $1=$ dostępna & $1=$ punkt widokowy & 1 = dostępna & $1=$ parking & 1 = dostępne & $\begin{array}{l}1=\text { zabytki } \\
\text { historyczne lub } \\
\text { obiekty kultury }\end{array}$ \\
\hline \multirow[t]{4}{*}{$\begin{array}{l}2=\text { kilka } \\
\text { rodzajów }\end{array}$} & $\begin{array}{l}2=\text { szlaki } \\
\text { turystyczne, ścieżki }\end{array}$ & $2=$ kilka rodzajów & $\begin{array}{l}2=\text { publiczne środki } \\
\text { transportu }\end{array}$ & 2 = kilka rodzajów & $\begin{array}{l}2=\text { obiekty przyrody } \\
\text { ożywionej, np. } \\
\text { obserwacja ptaków }\end{array}$ \\
\hline & $\begin{array}{l}3=\text { ośrodek } \\
\text { informacji } \\
\text { turystycznej }\end{array}$ & & $3=$ zakwaterowanie & & $3=$ inne \\
\hline & $\begin{array}{l}4=\text { tablice } \\
\text { informacyjne }\end{array}$ & & $\begin{array}{l}4=\text { wydzielone } \\
\text { miejsca piknikowe }\end{array}$ & & \\
\hline & $5=$ inne & & $5=$ inne & & \\
\hline
\end{tabular}

Tab. 2. Wyjściowe kryteria kwalifikacji i cech charakterystycznych badanych map

* - kryteria uwzględniane w hierarchicznej analizie klastrowej 
geomorfologiczne. Różnica pomiędzy typem 3 a 4 polega na innym sposobie przedstawienia geoobiektów: na mapach typu 3 są to symbole punktowe, natomiast na mapach typu 4 -klasyczne oznaczenia kartograficzne. Jakość przekazywanej informacji naukowej w obu typach map jest na wysokim poziomie, natomiast jakość informacji turystycznej jest zróżnicowana: od przeciętnej w typie 3 do wysokiej w typie 4.

\section{Typ5: Mapy geoedukacyjne}

Określenie to wynika $\mathrm{z}$ charakteru tych map. Z jednej strony stosowane są tu zestawy różnych symboli naniesione na schematycznie przedstawione tło $\mathrm{w}$ dużej skali, co pozwala na pokazanie form rzeźby terenu, z drugiej strony ten typ oferuje turyście dobry zestaw treści objaśniających różne problemy z zakresu nauk o Ziemi oraz informację turystyczną.

\section{Dyskusja}

Jak wspomniano wyżej, zakresy przekazywanej informacji naukowej i turystycznej różnią się bardzo znacznie w poszczególnych grupach map. Zróżnicowanie to sięga od map przeglądowych (typ 1), które pokazują głównie lokalizację geoobiektów do map przeznaczony ch dla amatorów nauk o Ziemi (typy 3 i 4), które zawierają szczegółową informację geologiczną, geomorfologiczną i turystyczną. Rozważając problem informacji dostarczanej przez mapy należy uwzględnić także efektywność ich wykorzystania. Lehnes i Glawion (2006) uważają, że turyści odwiedzą dany obiekt czy obszar tylko wtedy, gdy będą mieli przeświadczenie, że podjęty wysiłek wart jest wrażeń, jakich dostarczy im dane miejsce. Stosując tę zasadę do czytania informacji przedstawionych na mapach dochodzimy do wniosku, że przeciętny turysta chciałby wprawdzie uzyskać potrzebną informację, ale raczej nie jest gotów dokładnie studiować mapę by zrozumieć przedstawione na niej szczegóły.

Z tego punktu widzenia mapy przeglądowe (typ 1) i mapy geoturystyczne (typ 2), zawierają niewiele przydatnych informacji. Oczywiście, są one nadal źródłem danych o interesujących miejscach w zwiedzanym regionie i mogą być użyteczne przy planowaniu wycieczek w sensie wyboru obiektów zwiedzania i uzyskania podstawowej informacji turystycznej. Niestety, nie dostarczają one informacji naukowej, której trzeba szukać w dołączonych do map broszurach i fotografiach.

Mapy przeznaczone dla amatorów nauk o Ziemi (typy 3 i 4) zawierają szczegółowe dane geologiczne i geomorfologiczne, przyczyniając się w ten sposób upowszechniania wiedzy. Pomimo uproszczeń treści mapy te posiadają rozbudowane legendy, zawierające np. kompletne tabele litostratygraficzne, czy też oznaczenia elementów strukturalnych. Korzystanie $\mathrm{z}$ takich map wymaga jednak dość zaawansowanej wiedzy z zakresu nauk o Ziemi. Autorka uważa, że przeciętny turysta może być tym zniechęcony, wskutek czego sięgnie raczej po opisy poszczególnych obiektów zawarte w dołączonym tekście i fotografie umieszczone na marginesach lub na odwrocie mapy. W takim przypadku wspomniana wyżej równowaga pomiędzy wysiłkiem włożonym w czytanie mapy a korzyściami nie zostanie zachowana.

W przypadku analizowanych map geoedukacyjnych (typ 5) widoczne są wysiłki autorów zmierzające do uproszczenia ich treści. Ponieważ są to mapy obszarów średniej wielkości, możliwe jest przedstawienie form morfologicznych terenu przy pomocy symboli figuratywnych, co od razu kieruje uwage turysty na takie obiekty. Tak więc podstawowa informacja zostaje nie tylko uproszczona, ale też ,przełożona” na język zrozumiały dla nie-specjalisty. W taki sposób rozszerzamy zakres informacji, którą można odczytać bezpośrednio z mapy, bez sięgania do tekstu czy fotografii. Ponadto mapy geoedukacyjne zawierają informację turystyczną, która zwraca uwagę zwiedzającego na inne ciekawostki znajdujące się w pobliżu geoobiektów i maksymalnie ułatwia orientację w terenie. W ten sposób tworzymy mapy łatwe do czytania. Ciekawe, że mapy przeglądowe i geoturystyczne (typy 1 i 2 ) stanowiły blisko połowę (46\%) analizowanej populacji. Mapy przeznaczone dla amatorów nauk o Ziemi (typy 3 i 4) stanowiły $38 \%$ badanych materiałów, a najbardziej użyteczne mapy geoedukacyjne - jedynie 14\% analizowanych map (Fig. 2).

\section{Wnioski}

W przeciwieństwie do praktyki szeroko stosowanej w tworzeniu materiałów tekstowych popularyzujących nauki o Ziemi, zasady upraszczania informacji graficznej są nadal w powijakach. Tworzenie map geoturystycznych odbywa się przy pomocy niejasnych zasad, a ich autorzy wydają się kierować raczej względami estetycznymi, niż wymogami dydaktyki. Analiza wykazała, że potencjał informacyjny takich map jest niewykorzystany. Aby mapy spełniały swoje zadanie konieczne jest zbadanie potrzeb turystów (szczególnie ich oczekiwań w stosunku do map) i sposobu, w jaki przyswajają podawane sobie informacje (Pralong, 2006; Reynard \& Berrebi, w druku). Wyniki takich badań mogłyby znacząco wpłynąć na efektywność wykorzystania map jako źródła informacji turystycznej, a tym samym polepszyć jakość ofert turystycznych.

\section{References (Literatura)}

Bavaud, F., 1999. Modèles et données: une introduction à la statistique uni-, bi-et trivariée. Paris, L'Harmattan.

Bertacchini, M., Benito, A. \& Castaldini, D., 2007. Carta GeoArcheo-Turistica del territorio di Otricoli (Terni, Umbria). Geologia e turismo, Bologna 1-3 marzo 07, Poster Proceedings.

Bissig, G. 2007. Ways to map geosites: an analysis of the existing cartography and methods. Workshop "Geomorphosites, Geoparks and Geotourism”, Lesvos (Greece), 30.09-3.10.2007, Abstract book.
Bissig, G. (underway). Perception des éléments géomorphologiques du paysage et représentation cartographique géodidactique. Thèse de doctorat, Faculté des Géosciences, Université de Lausanne.

Bruschi, V.M. \& Cendrero, A., 2005. Geosite evaluation. Can we measure intangible values? Il Quaternario, 18(1): 293-306.

Carton, A., Coratza, P. \& Marchetti, M., 2005. Guidelines for geomorphological sites mapping: examples from Italy. Géomorphologie: relief, processus, environnement, 3: 209-218. 
Castaldini D., Valdati J., \& Ilies D.C., 2005a. The contribution of geomorphological mapping to environmental tourism in protected areas: examples from the Apennines of Modena (Northern Italy). Revista de geomorfologie, 7: 91-106.

Castaldini D., Valdati J., Ilies D.C., \& Chiriac C., 2005b. Geo-tourist map of the natural reserve of Salse di Nirano (Modena Apennines, Northern Italy). Il Quaternario, 18(1): 245-255.

Coratza, P. \& Giusti, C., 2005. Methodological proposal for the assessment of the scientific quality of geomorphosites. Il Quaternario. Italian Journal of Quaternary Sciences, 18(1): 307-313.

Grandgirard, V., 1997. Géomorphologie, protection de la nature et gestion $d u$ paysage, Thèse de doctorat, Faculté des Sciences, Université de Fribourg.

Grandgirard, V., 1999. L'évaluation des géotopes. Geologia Insubrica, 4: 59-66.

Gustavsson M., Kolstrup E., \& Seijmonsbergen A.C., 2006. A new symboland-GIS based detailed geomorphological mapping system: Renewal of a scientific discipline for understanding landscape development. Geomorphology, 77: 90-111.

Hose, T.A., 2006. Geotourism and interpretation. In: Dowling, R. \& New some D., (ed), Geotourism, Amsterdam, Elsevier, 221-241.

Kruhl, J. H., 2006. Rahmenbedingungen einer Geotop- und Geopark-bezogenen Didaktik. In: Vogt, J. \& Mergele, A. (Hrsg.), Geopark- und Geotourismusforschung. Ergebnisse des internationalen Workshops in Karlsruhe 2006. Regionalwissenschaftliche Forschung, 31: 41-49.

Lambiel , C. \& Reynard, E., 2003. Impacts du développement d'un domaine skiable sur la morphologie glaciaire et périglaciaire: le cas de Verbier (Valais, Suisse). Géomorphologie et tourisme. Travaux et recherches 24, Lausanne, Institut de Géographie: 19-33.

Lambiel, C., Bardou, E., Delaloye, R., Schoeneich, P., Schütz, P., 2008. Permafrost-Vaud. Rapport d'étude (non publié), Institut de Géographie, Université de Lausanne.

Lehnes, P. \& Glawion, R., 2006. Landschaftsinterpretation. Erd- und Landschaftsgeschichte als Freizeit-Erlebnis. Geographie und Schule, G21265, 28. Jahrgang, 159: 23-28.

Frey, M.-L., 2001. European Geoparks, Geological heritage \& European identity - cooperation for a common future. European Geoparks Magazine, 1: 4-6.

Newsome, D. \& Dowling, R., 2006. The scope and nature of geotourism. In: Dowling, R. \& Newsome, D. (ed.), Geotourism, Amsterdam, Elsevier, 3-25.

Panizza, M. \& Piacente, S., 1993. Geomorphological assets evaluation. Zeitschrift für Geomorphologie, N.F., Suppl. Bd. 87: 13-18.
Panizza, M. \& Piacente, S., 2003. Geomorphologia culturale. Bologna, Pitagora.

Pelfini, M., Brandolini, P., Carton, A., Piccazzo, M. 2007. Rappresentazione in carta delle caratteristiche dei sentieri ai fini della mitigazione del rischio geomorfologico. in press.

Pereira, P., Pereira, D. \& M. Caetano Alves, 2007. Geomorphosite assessment in Montesinho Natural Park (Portugal). Geographica Helvetica 62, 3: $159-168$.

Pralong, J.-P., 2005. A method for assessing the tourist potential and use of geomorphological sites. Géomorphologie. Relief, processus, environnement, 3: 189-196

Pralong, J-P., 2006. Géotourisme et utilisation de sites naturels d'intéręt pour les sciences de la Terre: les régions de Crans-Montana-Sierre (Valais, Alpes suisses) et Chamonix-Mont-Blanc (Haute-Savoie, Alpes françaises). Thčse de doctorat, Faculté des Géosciences, Université de Lausanne.

Reynard, E., Fontana, G., Kozlik, L., \& Scapozza, C., 2007. A method for assessing "scientific" and "additional values" of geomorphosites. Geographica Helvetica, 3: 148-58.

Reynard, E., 2004. Géotopes, géo(morpho)sites et paysages géomorphologiques. In: Reynard, E. \& Pralong J.-P. (eds), Paysages géomorphologiques. Travaux et recherches 27, Lausanne, Institut de Géographie: 123-136.

Reynard, E., 2005. Geomorphosites et paysages. Géomorphologie: relief, processus, environnement, 3: 181-188.

Reynard, E., Berrebi, Y., (submitted). Percorsi geodidattici e aspettative del pubblico, Atti del Terzo congresso nazionale Geologia e Turismo, Bologna 1-3 marzo 2007

Serrano, E. \& Gonzalez-Trueba, J.J., 2005. Assessment of geomorphosites in natural protected areas: the Picos de Europa National Park (Spain). Géomorphologie: relief, processus, environnement, 3: 197-208.

Strasser, A., Heitzmann, P., Jordan, P., Stapfer, A., Stürm, B., Vogel, A., Weidmann, M., 1995. Géotopes et la protection des objets géologiques en Suisse: un rapport stratégique, Fribourg, Groupe de travail pour la protection des géotopes en Suisse.

Wang, G. 2006. Entwicklung eines Geotop-Monitoring-Systems, angewand auf den Teilraum Lenninger Alb. Eberhard-Karls-Universität Tübigen. Diplomarbeit.

Wölfl, C., 2006. Grundlage für die Planung geodidaktischer Angebote. In: Rosendahl, W., Junker, B., Mergele, A. \& Vogt, J. (Hrsg.), Geotope-Bausteine der Regionalentwicklung. Schriftenreihe der Deutschen Gesellschaft für Geowissenschaften, 44: 60-66. 